\title{
S75. KEYNOTE LECTURE: Basic concept for the understanding of cancer mediated immune rejection
}

\author{
F Marincola ${ }^{1 *}$, E Wang $^{2}$ \\ From 1st Immunotherapy of Cancer Conference (ITOC1) \\ Munich, Germany. 12-14 March 2014
}

\section{Background}

Cancer is a multi-genic, complex biological phenomenon and its growth is affected by various categories of factors including the genetics of the host, the accumulating genetic alteration within cancer cells and environmental modifiers.

\section{Material and methods}

Therefore, to identify the determinants of immunemediated tumor rejection during immunotherapy, a systematic and comprehensive monitoring approach needs to be applied that covers the various categories at a time relevant to the therapeutic intervention. In addition, a temporal dimension needs to be added to evaluate in real time the changes induced by treatment and their relationship with clinical outcome.

\section{Results}

In this presentation, we will review the salient concepts that should guide the future monitoring of clinical trials taking advantage of novel and comprehensive technological advances presenting examples of integrated approaches for the assessment of patients' response to adoptive $\mathrm{T}$ cell therapy.

\section{Conclusions}

Our experience highlights the need to apply multiparametric approaches for the understanding of the mechanism(s) leading to cancer rejection by the immune system in humans.

\author{
Authors' details \\ ${ }^{1}$ Sidra Medical and Research Center, Doha, Qatar. ${ }^{2}$ Sidra Medical and \\ Research Center, Research Branch, Doha, Qatar.
}

Published: 12 March 2014

doi:10.1186/2051-1426-2-S2-I13

Cite this article as: Marincola and Wang: S75. KEYNOTE LECTURE: Basic concept for the understanding of cancer mediated immune rejection. Journal for ImmunoTherapy of Cancer 2014 2(Suppl 2):113.

${ }^{1}$ Sidra Medical and Research Center, Doha, Qatar

Full list of author information is available at the end of the article

Submit your next manuscript to BioMed Central and take full advantage of:

- Convenient online submission

- Thorough peer review

- No space constraints or color figure charges

- Immediate publication on acceptance

- Inclusion in PubMed, CAS, Scopus and Google Scholar

- Research which is freely available for redistribution
C Biomed Central

(c) 2014 Marincola and Wang; licensee BioMed Central Ltd. This is an Open Access article distributed under the terms of the Creative Commons Attribution License (http://creativecommons.org/licenses/by/2.0), which permits unrestricted use, distribution, and reproduction in any medium, provided the original work is properly cited. The Creative Commons Public Domain Dedication waiver (http://creativecommons.org/publicdomain/zero/1.0/) applies to the data made available in this article, unless otherwise stated. 